\title{
IN VITRO ANTIOXIDANT CAPACITY AND FREE RADICAL SCAVENGING ACTIVITIES OF CARDIOSPERMUM HALICACABUM LINN.
}

\author{
SAVITHA G ${ }^{1 *}$, VISHNUPRIYA V ${ }^{2}$, SURAPANENI KRISHNAMOHAN \\ ${ }^{1}$ Department of Biochemistry, Saveetha Dental College, SIMATS, Saveetha University, Chennai, Tamil Nadu, India. ${ }^{2}$ Department of \\ Biochemistry, Saveetha Dental College, SIMATS, Saveetha University, Chennai, Tamil Nadu, India. Department of Biochemistry, Chettinad \\ Hospital and Research Institute, Chettinad Health City, Kelambakkam. Email: drsavitha80@gmail.com
}

Received: 09 February 2018, Revised and Accepted: 02 April 2018

\section{ABSTRACT}

Objective: Free radicals and oxidants are produced in the body during normal cellular metabolism and exposure to pollutions and ionizing radiations. They exert beneficial and harmful effects to the human body. Harmful effects of these radicals are destroyed by either antioxidants of our body in situ or antioxidants which are supplied through foods. Hence, the aim of this present study is to assess the antioxidant and free radical scavenging capacity of the easily available edible plant Cardiospermum halicacabum Linn. (Mudakathan keerai).

Methods: Antioxidant and free radical scavenging activities of the aerial parts extract of $C$. halicacabum was determined by 2,2-diphenyl-1picrylhydrazyl (DPPH) radical scavenging assay, 2,2-azino-bis(3-ethylbenzothiazoline-6-sulfonic acid) (ABTS) radical scavenging assay, ferrous ion chelating assay, nitric oxide (NO) radical scavenging assay, superoxide radical scavenging assay, hydroxyl radical scavenging assay, and lipid peroxidation assay.

Results: Remarkable free radical scavenging potential was observed in the ethanolic extract of $C$. halicacabum with $\mathrm{IC}_{50}$ values on all tested radicals, namely DPPH $\left(\mathrm{IC}_{50}=34.06 \mu \mathrm{g} / \mathrm{ml}\right), \mathrm{ABTS}\left(\mathrm{IC}_{50}=21.45 \mu \mathrm{g} / \mathrm{ml}\right)$, ferrous ion chelating $\left(\mathrm{IC}_{50}=19.56 \mu \mathrm{g} / \mathrm{ml}\right), \mathrm{NO}\left(\mathrm{IC}_{50}=25.16 \mu \mathrm{g} / \mathrm{ml}\right)$, superoxide (IC50=35.16 $\mu \mathrm{g} / \mathrm{ml}$ ), hydroxyl (IC50 $=28.56 \mu \mathrm{g} / \mathrm{ml}$ ), and lipid peroxidation (IC50=33.12 $\mu \mathrm{g} / \mathrm{ml}$ ). The results revealed that ethanolic extract of C. halicacabum Linn. has significant antioxidant activity.

Conclusion: The present study suggested that the aerial part extract of $C$. halicacabum serves as a good source of natural antioxidants.

Keywords: Antioxidants, Cardiospermum halicacabum Linn., Free radicals scavenging activity.

(C) 2018 The Authors. Published by Innovare Academic Sciences Pvt Ltd. This is an open access article under the CC BY license (http://creativecommons. org/licenses/by/4. 0/) DOI: http://dx.doi.org/10.22159/ajpcr.2018.v11i7.25044

\section{INTRODUCTION}

Free radicals are chemically reactive oxygen or nitrogen containing molecules that are generated as a natural by-product of the cell metabolism. Free radicals are constantly generated and eliminated under normal physiologic conditions and have important functions in cell signaling, homeostasis, and clearance of microbial infections. Free radicals have unpaired electron in the outer shell of the molecule. Hence, these free radicals are highly reactive. These radicals attack the nearest stable molecules, stealing its electron. When the attacked molecule loses its electron, it becomes a free radical itself, beginning a chain reaction, finally resulting in disruption of a living cell. Free radicals may be either oxygen-derived reactive oxygen species or nitrogen-derived reactive nitrogen species. The oxygen-derived molecules are superoxide $\left(\mathrm{O}^{-}\right)$, hydroxyl $(\mathrm{HO})$, hydroperoxyl $\left(\mathrm{HO}_{2}\right)$, peroxyl (ROO), and alkoxyl (RO) as free radicals and $\mathrm{H}_{2} \mathrm{O}_{2}$, oxygen as non-radical. Nitrogen-derived oxidant species are mainly nitric oxide (NO), peroxynitrate (ONOO), nitrogen dioxide $\left(\mathrm{NO}_{2}\right)$, and dinitrogen trioxide $\left(\mathrm{N}_{2} \mathrm{O}_{3}\right)$. In a normal cell, there is a balance between oxidant and antioxidant. During times of environmental stress such as exposure to ionizing and ultraviolet radiation (UV) or heat, environmental pollutants, or during infection, free radicals are generated more in the body and the oxidant-antioxidant balance is disturbed which leads to oxidative stress. Oxidative stress can result in damage to cellular proteins, lipids, and DNA, leading to variety of human diseases such as inflammation, autoimmune diseases, diabetes, cardiovascular disease, cancer, and aging $[1,2]$.

Antioxidants are the substances that significantly delay or prevent oxidation of oxidizable substrates when present at lower concentrations than the substrate [3]. The excessive production of free radicals should be neutralized or minimized by effective antioxidative system comprising of non-enzymatic as well as enzymatic antioxidants [4]. The enzymatic antioxidants which include superoxide dismutase, catalase, and glutathione peroxidase are present in plasma and non-enzymatic antioxidants include albumin, transferrin, ceruloplasmin, tocopherol (Vitamin E), quinines, bilirubin, ascorbic acid (Vitamin C), uric acid, copper, manganese, zinc, and carotenoids (Vitamin A) [5].

Antioxidants may be synthetic or natural. Synthetic antioxidants such as butylated hydroxytoluene (BHT) and butylated hydroxyanisole are widely used in food industry, cosmetics, and therapeutic industry. Synthetic antioxidants are highly volatile and instable in elevated temperature and carcinogenic in nature [6]. Due to these reasons, people have switched to nature. Many phytocompounds present in plants, vegetable, and fruits have free radical scavenging or active oxygen scavenging capacity. These are called natural antioxidants. Flavonoids and phenolic acids are most important groups of secondary metabolites and bioactive compounds in plants, and they are good sources of natural antioxidants in human diets. Due to their antioxidant properties, the plants show antiulcer, anti-inflammatory, antimicrobial, cytotoxic, and antitumor activities [7].

The family Sapindaceae has a wide spread of distribution with 136 genera and 2000 species. Ethnomedicinal information revealed that the extracts from members of this family are commonly used for the treatment of boils, ulcers, pain, dermatological troubles, wound healing, rheumatism, diarrhea, and dysentery [8]. Cardiospermum halicacabum Linn. belongs to family Sapindaceae. Common name is 
Balloon vine or Love in a puff. Tamil name is Mudakathan [9]. They are widely distributed in tropical and subtropical areas of the world. This plant is produced in the plains of Asia and Africa. It is used in the treatment of rheumatism, nervous diseases, stiffness of the limbs, and snakebite $[10,11]$. Preliminary phytochemical screening of the ethanolic extract of $C$. halicacabum revealed the presence of alkaloids, flavonoids, saponins, proteins, carbohydrates, tannins, and glycosides [12,13]. Hence, the objective of the present study is to assess the antioxidant and free radical scavenging properties of the aerial part extract of C. halicacabum by 2,2-diphenyl-1-picrylhydrazyl (DPPH) radical scavenging activity, 2,2-azino-bis(3-ethylbenzothiazoline-6-sulfonic acid) (ABTS) radical scavenging activity, ferrous ion chelating activity, NO radical scavenging activity, superoxide radical scavenging activity, hydroxyl radical scavenging activity, and lipid peroxidation activity.

\section{METHODS}

Dried powdered form of aerial parts of $C$. halicacabum extract was obtained from Green Chem, Bengaluru.

Antioxidant and free radical scavenging activities of the aerial parts extract of $C$. halicacabum were determined by DPPH radical scavenging assay, ABTS radical scavenging assay, hydroxyl radical scavenging assay $[8,14,15]$, ferrous ion chelating assay, NO radical scavenging assay, superoxide radical scavenging assay, and lipid peroxidation assay method [16].

\section{DPPH scavenging activity}

The antioxidant activity of the extract was estimated on the basis of the radical scavenging effect of the stable DPPHi. Various concentrations of the extract were added to a methanolic $0.4 \mathrm{mM}$ DPPHi solution $(0.1 \mathrm{ml})$ in a 96 -well plate. The reaction mixture was shaken vigorously and allowed to stand for $30 \mathrm{~min}$ at $37^{\circ} \mathrm{C}$. The degree of DPPHi purple decolorization to DPPH yellow indicated the scavenging efficiency of the extract. The absorbance of the mixture was determined at $517 \mathrm{~nm}$ using UV-visible microplate reader, and ascorbic acid was served as a positive control. The scavenging activity against DPPHi was calculated using the following equation:

Scavenging activity $(\%)=[1-(\mathrm{A} 1-\mathrm{A} 2) / \mathrm{A} 0] \times 100 \%$

Where

A0 was the absorbance of control (DPPHi solution without the extract),

A1 was the absorbance of DPPHi solution in the presence of the extract, and

A2 was the absorbance without DPPH solution.

\section{ABTS radical scavenging activity}

ABTS radical cation was produced by the reaction of a $7 \mathrm{mmol} / \mathrm{L}$ ABTS solution with $2.45 \mathrm{mmol} / \mathrm{L}$ potassium persulfate. The mixture was stored in the dark at room temperature for $12 \mathrm{~h}$ before use. The $\mathrm{ABTS}^{+}$solution was diluted with ethanol to an absorbance at $734 \mathrm{~nm}$. After addition of $25 \mu \mathrm{L}$ of sample or standard to $2 \mathrm{~mL}$ of diluted ABTS ${ }^{+}$ solution, absorbance at $734 \mathrm{~nm}$ was read after $6 \mathrm{~min}$. A standard curve was prepared by measuring the reduction in absorbance of ABTS • ${ }^{+}$ solution at different concentrations of extract. Appropriate blank measurements were carried out and the values were recorded with ascorbic acid as the positive control.

\section{Ferrous ion chelating activity}

The extract $(2 \mathrm{ml})$ was added to a solution of $2 \mathrm{mM} \mathrm{FeCl}_{2}(0.1 \mathrm{ml})$. The reaction was initiated by the addition of $5 \mathrm{mM}$ ferrozine $(0.2 \mathrm{ml})$, and the mixture was shaken vigorously and left standing at room temperature for $5 \mathrm{~min}$. Absorbance was measured at $562 \mathrm{~nm}$ and ethylenediaminetetraacetic acid (EDTA) was used as a positive control. The percentages of inhibition of ferrozine- $\mathrm{Fe}^{2+}$ complex formation were given by the following formula:

Ferrous ion chelating activity $(\%)=[1-(\mathrm{A} 1-\mathrm{A} 2) / \mathrm{A} 0] \times 100 \%$
Where

A0 was the absorbance of the control (the mixture without the extract), A1 was the absorbance of the mixture in the presence of the extract, and A2 was the absorbance without ferrozine.

\section{Nitric oxide radical scavenging assay}

At physiological pH, aqueous solution of Sodium nitroprusside (SNP), spontaneously generated iNO which interacted with oxygen to produce nitrite ion, which was estimated by using Griess reagent. The reaction mixture containing $2 \mathrm{ml}$ of the extract at different concentrations and $50 \mathrm{mM}$ SNP $(0.5 \mathrm{ml})$ in $10 \mathrm{mM}$ PBS was incubated at $37^{\circ} \mathrm{C}$ for $60 \mathrm{~min}$. An aliquot $(0.5 \mathrm{ml})$ of the incubated solution was pipetted out and diluted with $0.5 \mathrm{ml}$ of Griess reagent (1\% sulfanilamide in $5 \% \mathrm{H}_{3} \mathrm{PO}_{4}$ and $0.1 \% \mathrm{~N}$-(1-naphthyl) ethylenediamine dihydrochloride [NED]). The absorbance of the chromophore that formed during diazotization of nitrite with sulfanilamide and subsequent coupling with NED was immediately recorded at $540 \mathrm{~nm}$. The absorbance from various concentrations of sodium nitrite salt treated the same way with Griess reagent was plotted for a standard curve. $\alpha$-tocopherol was used as a standard. The capability to scavenge iNO radicals was calculated using the following equation:

Scavenging activity $(\%)=[1-(\mathrm{A} 1-\mathrm{A} 2) / \mathrm{A} 0] \times 100 \%$

Where

A0 was the absorbance of the control (the reaction mixture without the extract),

A1 was the absorbance in the presence of the extract, and

A2 was the absorbance without Griess reagent.

\section{Superoxide radical scavenging activity}

The assay was based on the capacity of the plant extracts to inhibit nitro blue tetrazolium (NBT) up to $50 \%$ in the presence of riboflavin-light-NBT system. The reaction medium contains $50 \mathrm{mM}$ phosphate buffer $\mathrm{pH}$ 7.6, $20 \mu \mathrm{g}$ riboflavin, $12 \mathrm{mM}$ EDTA, different concentrations of extract (5$200 \mu \mathrm{g} / \mathrm{ml}$ ), and NBT $0.1 \mathrm{mg} / 3 \mathrm{ml}$, and BHT was taken in different test tube and the same reagents were added. The reaction was started by illuminating the sample cuvette at regular intervals of $30 \mathrm{~s}$, and increases in absorbance were measured at $590 \mathrm{~nm}$ up to $2.5 \mathrm{~min}$. The superoxide radical scavenging activity was calculated using the following formula:

$\%$ inhibition of superoxide radical= OD (extract absent) - OD (extract present)/OD (extract absent).

\section{Hydroxyl radical scavenging activity}

The effect of extract on hydroxyl radical was assessed using the deoxyribose method. The reaction mixture contained $450 \mu \mathrm{l}$ of $0.2 \mathrm{M}$ sodium phosphate buffer ( $\mathrm{pH} 7.0$ ), $150 \mu \mathrm{l}$ of $10 \mathrm{mM}$ 2-deoxyribose, $150 \mu \mathrm{l}$ of $10 \mathrm{mM} \mathrm{FeSO}_{4}$-EDTA, $150 \mu \mathrm{l}$ of $10 \mathrm{mM} \mathrm{H}_{2} \mathrm{O}_{2}, 500 \mu \mathrm{l}$ of $\mathrm{H}_{2} \mathrm{O}$, and $100 \mu \mathrm{l}$ of sample solution $(5-200 \mu \mathrm{g} / \mathrm{ml})$. The reaction was started by the addition of $\mathrm{H}_{2} \mathrm{O}_{2}$. After incubation at $37^{\circ} \mathrm{C}$ for $4 \mathrm{~h}$, the reaction was stopped by adding $750 \mu \mathrm{l}$ of $2.8 \%$ trichloroacetic acid and $750 \mu \mathrm{l}$ of $1 \%$ thiobarbituric acid in $50 \mathrm{mM} \mathrm{NaOH}$, and the solution was boiled for $10 \mathrm{~min}$ and then cooled in ice water. The absorbance of the solution was measured at $520 \mathrm{~nm}$. Here, ascorbic acid was used as positive control.

\section{Lipid peroxidation assay}

The liver homogenate was washed several times with ice-cold buffer solution $(0.15 \mathrm{M} \mathrm{KCl}, \mathrm{pH} 7.4)$. A $10 \%$ liver homogenate was prepared, and lipid peroxidation was initiated by the addition of $25 \mu \mathrm{M} \mathrm{FeSO}{ }_{4}$,

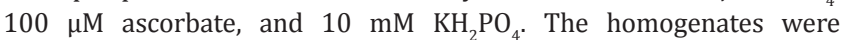
incubated at $37^{\circ} \mathrm{C}$ for $30 \mathrm{~min}$ with different concentrations of extract (5$200 \mu \mathrm{g} / \mathrm{ml}$ ). Lipid peroxidation was measured in terms of thiobarbituric acid reactive substances (TBARS) by extracting with $\mathrm{n}$-butanol and pyridine $(15: 1 . v / v)$. TBARS formed was determined at $532 \mathrm{~nm}$ OD.

The amount of effective concentration of extract needed to inhibit free radicals by $50 \% \mathrm{IC}_{50}$ was estimated from regression analysis between scavenging activities (\%) and various concentration of the extract [14]. 


\section{RESULTS}

The antioxidant and free radical scavenging activities of aerial parts extract of C. halicacabum Linn. was examined by DPPH, ABTS, NO, superoxide, hydroxyl radical scavenging activities, ferrous ion chelating activity, and lipid peroxidation activity.

\section{DISCUSSION}

The results of antioxidant activities of $C$. halicacabum extract revealed that the extract has significant antioxidant activities.

DPPH radical scavenging assay is an easy, rapid, and sensitive method for the antioxidant screening of plant extracts [17]. It was observed that free radical scavenging activity of the extract was increased with an increasing concentration of the extract. Percentage of inhibition on DPPH radical activity of extract was $19.74 \pm 1.3$ for the concentration of $5 \mu \mathrm{g} / \mathrm{ml}$ and $84.19 \pm 2.06$ for $200 \mu \mathrm{g} / \mathrm{ml}$ and IC $_{50}$ value was $34.06 \mu \mathrm{g} / \mathrm{ml}$ (Table 1 and Fig. 1a and b).

ABTS radical is stable and soluble in water and organic solvents, enabling the determination of antioxidant capacity of both hydrophilic and lipophilic compounds/samples [18]. Percentage of inhibition on ABTS radical activity of extract was $3.86 \pm 0.26$ for the concentration of $5 \mu \mathrm{g} / \mathrm{ml}$ and $89.6 \pm 0.24$ for $200 \mu \mathrm{g} / \mathrm{ml}$ and $\mathrm{IC}_{50}$ value was $21.45 \mu \mathrm{g} / \mathrm{ml}$ (Table 2 and Fig. 2a and b).

Ferrous ions are the most powerful pro-oxidant among the various species of metal ions. Hence, it acts as an important lipid oxidation prooxidant, which causes severe oxidative damage. Minimizing ferrous ion may exhibit protection against oxidative damage by inhibiting production of ROS and molecular damage [19]. Ferrous ion chelating ability of the extract was increased with concentration. Percentage of ferrous ion chelation of the extract was $29.13 \pm 2.1$ for the concentration of $5 \mu \mathrm{g} / \mathrm{ml}$ and $85.17 \pm 1.58$ for $200 \mu \mathrm{g} / \mathrm{ml}$ and $\mathrm{IC}_{50}$ value was $19.56 \mu \mathrm{g} / \mathrm{ml}$ (Table 3 and Fig. 3a and b).

Low concentrations of NO are essential for the physiological function because NO is an intracellular messenger for modulating blood flow, thrombosis, and neural activity [20]. The toxicity of NO increases greatly when it reacts with the superoxide radical, forming the highly reactive peroxynitrite anion $\left(\mathrm{ONOO}^{-}\right)$[21]. It was observed that the extract scavenged the nitric oxide radical in a dose-dependent manner. Percentage of inhibition on NO radical scavenging activity of the extract was $10.41 \pm 0.89$ for the concentration of $5 \mu \mathrm{g} / \mathrm{ml}$ and $78.15 \pm 0.78$ for $200 \mu \mathrm{g} / \mathrm{ml}$ and $\mathrm{IC}_{50}$ value was $25.16 \mu \mathrm{g} / \mathrm{ml}$ (Table 4 and Fig. $4 \mathrm{a}$ and b).

In the living cells, superoxide radicals are generated by reduction of molecular oxygen into water in electron transport chain and they are formed by activated phagocytes such as monocytes, macrophages, eosinophils, and neutrophils. It is an important factor in the killing

Table 1: DPPH radical scavenging activity of $C$. halicacabum Linn.

\begin{tabular}{llll}
\hline Sample & $\begin{array}{l}\text { Concentration } \\
(\mu \mathrm{g} / \mathrm{ml})\end{array}$ & $\begin{array}{l}\text { \% of } \\
\text { inhibition }\end{array}$ & $\begin{array}{l}\mathbf{I C}_{50} \\
(\boldsymbol{\mu g} / \mathbf{m l})\end{array}$ \\
\hline Extract & 5 & $19.74 \pm 1.3$ & 34.06 \\
& 25 & $47.19 \pm 1.7$ & \\
& 50 & $61.75 \pm 0.68$ & \\
& 100 & $83.17 \pm 2.01$ & \\
Ascorbic & 200 & $84.19 \pm 2.06$ & \\
acid - Standard & $86.14 \pm 1.45$ & 17.13 \\
\multicolumn{4}{l}{$\begin{array}{l}\text { C. halicacabum: Cardiospermum halicacabum, DPPH: 2,2-diphenyl-1- } \\
\text { picrylhydrazyl }\end{array}$}
\end{tabular}

Table 2: ABTS radical scavenging activity of $C$. halicacabum Linn.

\begin{tabular}{llll}
\hline Sample & $\begin{array}{l}\text { Concentration } \\
(\boldsymbol{\mu g} / \mathbf{m l})\end{array}$ & $\begin{array}{l}\boldsymbol{\%} \text { of } \\
\text { Inhibition }\end{array}$ & $\begin{array}{l}\mathbf{I C}_{\mathbf{5 0}} \\
(\boldsymbol{\mu g} / \mathbf{m l})\end{array}$ \\
\hline Extract & 5 & $3.86 \pm 0.26$ & 21.45 \\
& 25 & $16.7 \pm 1.05$ & \\
& 50 & $30.12 \pm 2.4$ & \\
& 100 & $60.3 \pm 0.69$ & \\
Ascorbic acid - Standard & 100 & $89.6 \pm 0.24$ & \\
\hline
\end{tabular}

C. halicacabum: Cardiospermum halicacabum, ABTS: 2,2-azino-bis

(3-ethylbenzothiazoline-6-sulfonic acid)

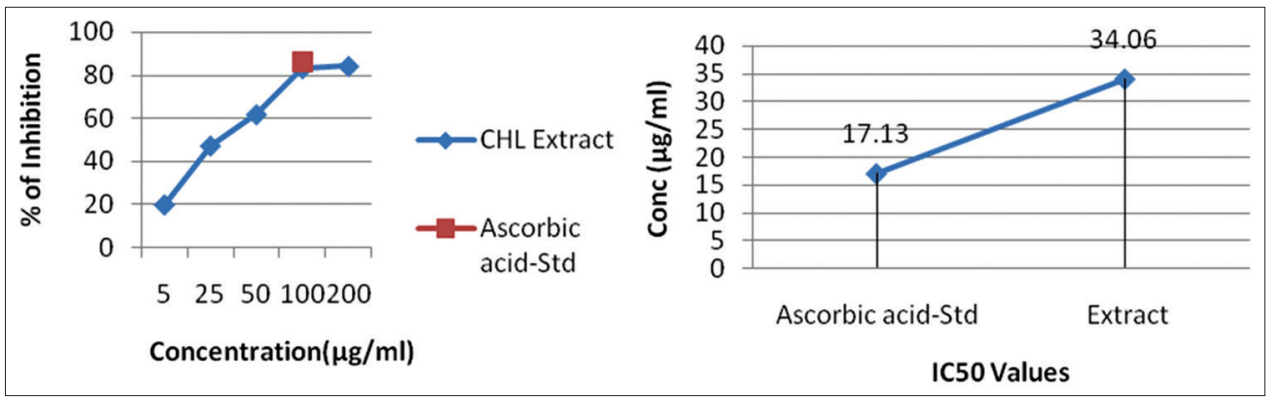

Fig. 1: (a) \% inhibition of 2,2-diphenyl-1-picrylhydrazyl radical scavenging activity of Cardiospermum halicacabum Linn. (b) IC (50 $_{\text {values of }}$ 2,2-diphenyl-1-picrylhydrazyl radical scavenging activity of C. halicacabum Linn.

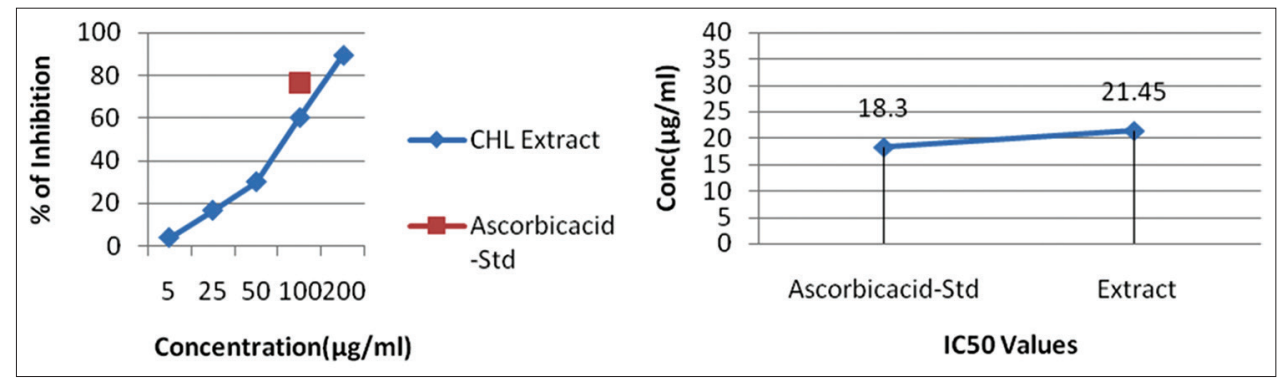

Fig. 2: (a) \% of inhibition of 2,2-azino-bis(3-ethylbenzothiazoline-6-sulfonic acid) (ABTS) radical scavenging activity of Cardiospermum halicacabum Linn. (b) IC ${ }_{50}$ Values of ABTS radical scavenging activity of $C$. halicacabum Linn. 


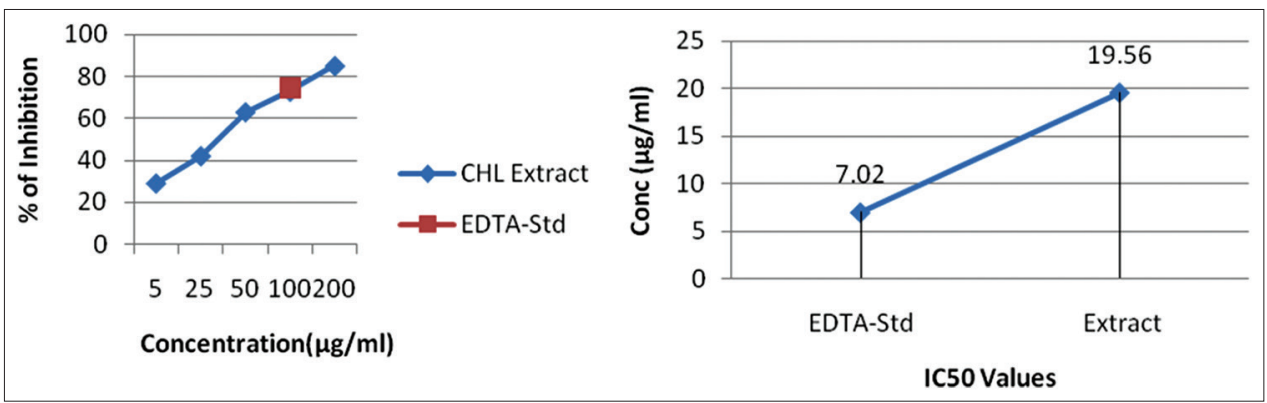

Fig. 3: (a) \% of inhibition of ferrous ion chelating activity of Cardiospermum halicacabum Linn. (b) $\mathrm{IC}_{50}$ values of ferrous ion chelating activity of $C$. halicacabum Linn.

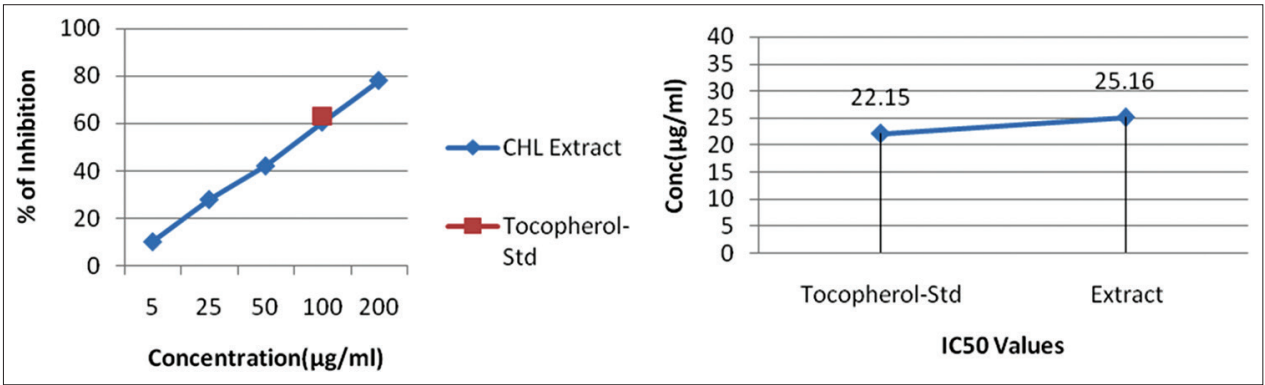

Fig. 4: (a) \% of inhibition of nitric oxide (NO) radical scavenging activity of Cardiospermum halicacabum Linn. (b) IC $\mathrm{I}_{50}$ values of NO radical scavenging activity of $C$. halicacabum Linn.

Table 3: Ferrous ion chelating activity of $C$. halicacabum Linn.

\begin{tabular}{llll}
\hline Sample & $\begin{array}{l}\text { Concentration } \\
(\boldsymbol{\mu g} / \mathbf{m l})\end{array}$ & $\begin{array}{l}\text { \% of } \\
\text { inhibition }\end{array}$ & $\begin{array}{l}\mathbf{I C}_{50} \\
(\boldsymbol{\mu g} / \mathbf{m l})\end{array}$ \\
\hline Extract & 5 & $29.13 \pm 2.1$ & 19.56 \\
& 25 & $42.16 \pm 1.08$ & \\
& 50 & $63.14 \pm 1.20$ & \\
& 100 & $72.91 \pm 0.58$ & \\
EDTA - Standard & 200 & $85.17 \pm 1.58$ & 7.02 \\
\hline
\end{tabular}

C. halicacabum: Cardiospermum halicacabum, EDTA: Ethylenediaminetetraacetic acid

Table 4: NO radical scavenging activity of $C$. halicacabum linn.

\begin{tabular}{llll}
\hline Sample & $\begin{array}{l}\text { Concentration } \\
(\boldsymbol{\mu g} / \mathbf{m l})\end{array}$ & $\begin{array}{l}\text { \% of } \\
\text { Inhibition }\end{array}$ & $\begin{array}{l}\mathbf{I C}_{50} \\
(\boldsymbol{\mu g} / \mathbf{m l})\end{array}$ \\
\hline Extract & 5 & $10.41 \pm 0.89$ & 25.16 \\
& 25 & $28.13 \pm 1.1$ & \\
& 50 & $42.26 \pm 0.94$ & \\
& 100 & $60.17 \pm 1.18$ & \\
Tocopherol - Standard & 100 & $78.15 \pm 0.78$ & \\
\hline
\end{tabular}

of bacteria by phagocytosis [22]. It is observed that the percentage of inhibition of extract on superoxide radical activity was $10.31 \pm 0.73$ for the concentration of $5 \mu \mathrm{g} / \mathrm{ml}$ and $87.6 \pm 1.53$ for $200 \mu \mathrm{g} / \mathrm{ml}$ and $\mathrm{IC}_{50}$ value was $35.16 \mu \mathrm{g} / \mathrm{ml}$ (Table 5 and Fig. $5 \mathrm{a}$ and b)

Hydroxyl radical is the neutral form of hydroxide ion and is a highly reactive free radical. It is formed in a fenton reaction, in which hydrogen peroxide reacts with metal ions $\left(\mathrm{Fe}^{2+}\right.$ or $\left.\mathrm{Cu}^{+}\right)$often bound in complex with different protein such as ferritin and ceruloplasmin or other molecules and it is formed by the reaction between superoxide radical and hydrogen peroxide in a reaction called Haber-Weiss reaction [23]. It was observed that the percentage of inhibition on hydroxyl radical scavenging activity of the extract was $5.67 \pm 0.42$ for the concentration
Table 5: Superoxide radical scavenging activity of C. halicacabum Linn.

\begin{tabular}{llll}
\hline Sample & $\begin{array}{l}\text { Concentration } \\
(\boldsymbol{\mu g} / \mathbf{m l})\end{array}$ & $\begin{array}{l}\text { \% of } \\
\text { Inhibition }\end{array}$ & $\begin{array}{l}\mathbf{I C}_{50} \\
(\boldsymbol{\mu g} / \mathbf{m l})\end{array}$ \\
\hline Extract & 5 & $10.31 \pm 0.73$ & 35.16 \\
& 25 & $19.86 \pm 0.46$ & \\
& 50 & $40.18 \pm 0.94$ & \\
& 100 & $71.16 \pm 1.06$ & \\
BHT - Standard & 200 & $87.6 \pm 1.53$ & 7.16 \\
\hline
\end{tabular}

C. halicacabum: Cardiospermum halicacabum

Table 6: Hydroxyl radical scavenging activity of $C$. halicacabum Linn.

\begin{tabular}{llll}
\hline Sample & $\begin{array}{l}\text { Concentration } \\
(\boldsymbol{\mu g} / \mathbf{m l})\end{array}$ & $\begin{array}{l}\text { \% of } \\
\text { Inhibition }\end{array}$ & $\begin{array}{l}\mathbf{I C}_{\mathbf{5 0}} \\
(\boldsymbol{\mu g} / \mathbf{m l})\end{array}$ \\
\hline Extract & 5 & $5.67 \pm 0.42$ & 28.56 \\
& 25 & $11.56 \pm 0.25$ & \\
& 50 & $28.56 \pm 0.89$ & \\
& 100 & $57.88 \pm 1.1$ & \\
Ascorbic & 200 & $79.69 \pm 2.3$ & \\
acid - Standard & 100 & $84.51 \pm 5.3$ & 12.24 \\
\hline
\end{tabular}

C. halicacabum: Cardiospermum halicacabum

of $5 \mu \mathrm{g} / \mathrm{ml}$ and $79.69 \pm 2.3$ for $200 \mu \mathrm{g} / \mathrm{ml}$ and $\mathrm{IC}_{50}$ value was $28.56 \mu \mathrm{g} / \mathrm{ml}$ (Table 6 and Fig. 6a and b).

Lipid peroxidation is a physiological process that takes place in all aerobic cells. Unsaturated fatty acids which are structural part of cell membranes are subjected to lipid peroxidation by a non-enzymatic and free radical mediated reaction chain. The destruction of cell membrane lipids and the end product of such lipid peroxidation reactions are dangerous for the viability of cells [24]. It was observed that the percentage of inhibition on lipid peroxidation activity of the extract 


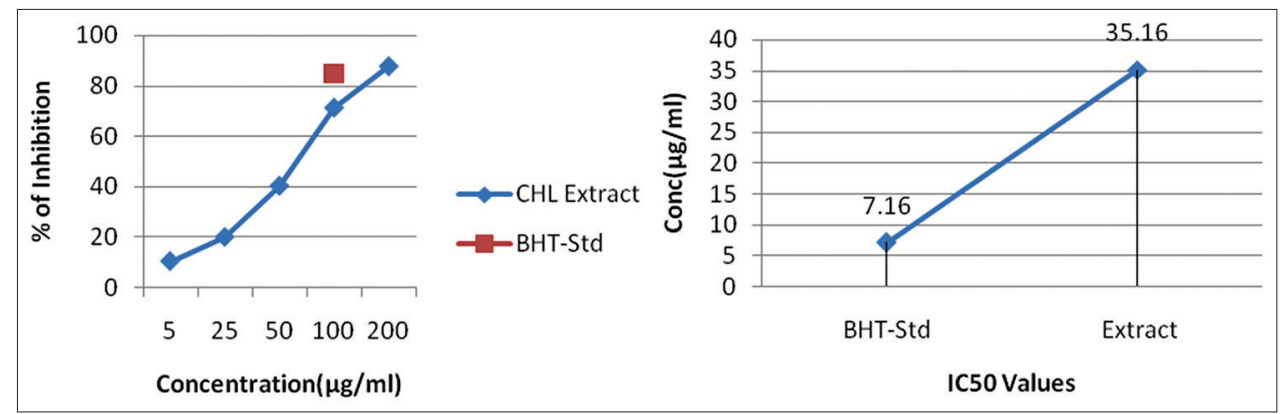

Fig. 5: (a) \% of inhibition of superoxide radical scavenging activity of Cardiospermum halicacabum Linn. (b) $\mathrm{IC}_{50}$ values of superoxide radical scavenging activity of $C$. halicacabum Linn.

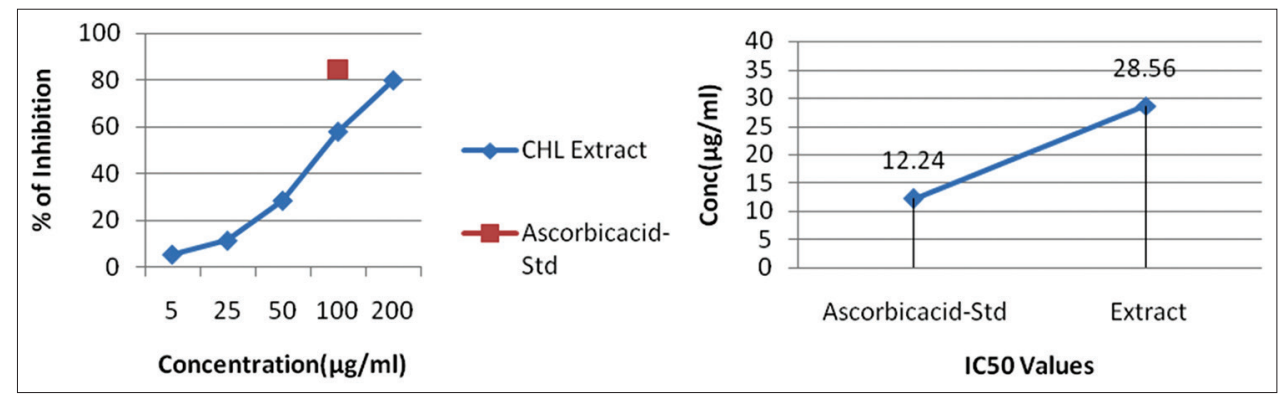

Fig. 6: (a) \% of inhibition of hydroxyl radical scavenging activity of Cardiospermum halicacabum Linn. (b) IC $_{50}$ values of hydroxyl radical scavenging activity of $C$. halicacabum Linn.

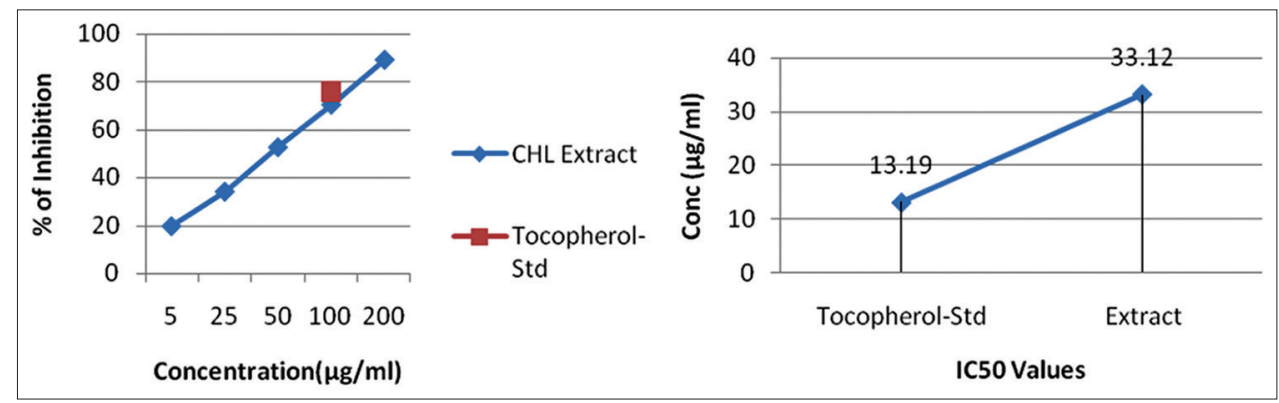

Fig. 7: (a) \% of inhibition of lipid peroxidation of Cardiospermum halicacabum Linn. (b) $\mathrm{IC}_{50}$ values of lipid peroxidation of $C$. halicacabum Linn.

Table 7: Lipid peroxidation of $C$. halicacabum Linn.

\begin{tabular}{llll}
\hline Sample & $\begin{array}{l}\text { Concentration } \\
(\boldsymbol{\mu g} / \mathbf{m l})\end{array}$ & $\begin{array}{l}\text { \% of } \\
\text { Inhibition }\end{array}$ & $\begin{array}{l}\mathbf{I C}_{\mathbf{5 0}} \\
(\boldsymbol{\mu g} / \mathbf{m l})\end{array}$ \\
\hline Extract & 5 & $19.78 \pm 1.05$ & 33.12 \\
(Tocopherol - Standard) & & & \\
& 25 & $34.13 \pm 3.12$ & \\
& 50 & $52.7 \pm 1.12$ & \\
& 100 & $70.45 \pm 2.89$ & \\
Tocopherol - Standard & 200 & $89.12 \pm 1.45$ & \\
\hline
\end{tabular}

C. halicacabum: Cardiospermum halicacabum

was $19.78 \pm 1.05$ for the concentration of $5 \mu \mathrm{g} / \mathrm{ml}$ and $89.12 \pm 1.45$ for $200 \mu \mathrm{g} / \mathrm{ml}$ and $\mathrm{IC}_{50}$ value was $33.12 \mu \mathrm{g} / \mathrm{ml}$ (Table 7 and Fig. 7a and b).

\section{CONCLUSION}

Due to our busy and stressful lifestyle, the production of free radicals in the body is increased. Free radicals play a dual role in the human body either they may be harmful or helpful. Excessive production and accumulation of these radicals cause oxidative stress which leads to disease to human body. The harmful effects of these radicals are destroyed by the substances called antioxidants which may be natural or synthetic. Due to these dangerous side effects and expensive of synthetic antioxidants, finding the natural antioxidants from easily available sources is indispensable. Thus, the current study on forgotten, economical, and readily reachable plant $C$. halicacabum (Mudakathan keerai) revealed the momentous antioxidant activity. Addition of this plant in our day-to-day life may prevent the occurrence of many diseases to human health.

\section{ACKNOWLEDGMENT}

The authors are grateful to Dr. MallikaJainu PhD., Director, Biogen care research centre, Chennai, for her providing and supporting necessary laboratory facilities for conduction of this research work and Mr. Rajendren, M.D of GREEN CHEM for his providing C. halicacabum Linn. extract for this research work.

\section{CONFLICTS OF INTEREST}

The authors of this article declare no conflict of interest in this study. 


\section{REFERENCES}

1. Eliades A, Massuura S, Ravid K. Oxidases and reactive oxygen species during hematopoiesis: A focus on megakaryocytes. J Cell Physio 2012;227:3355-62.

2. Badarinath AV, Rao KM, Sudhana Chetty CM, Ramkanth S, Rajan TV, Gnanaprakash K. A review on in-vitro antioxidants methods: Comparisions, correlations and considerations. Int J Pharm Tech Res 2010;2:1276-85.

3. Kasote DM, Katyare SS, Hegde MV, Bae H. Significance of antioxidant potential of plants and its relevance to therapeutic applications. Int $\mathbf{J}$ Biol Sci 2015;11:982-91.

4. Sharma P, Jha AB, Dubey RS, Pessarakli M. Reactive oxygen species, oxidative damage, and antioxidative defence mechanism in plants under stressful conditions. J Bot 2012;2012:26.

5. Gupta VK, Sharma SK. Plants as natural antioxidants. Nat Prod Radiance 2006;5:326-34.

6. Lobo V, Patil A, Phatak A, Chandra N. Free radicals, antioxidants and functional foods: Impact on human health. Pharm Rev 2010;4:118-26.

7. Saxena M, Saxena J, Pradhan A. Flavonoids and Phenolic acids as antioxidants in plants and human health. Int J Pharm Sci Rev Res 2012;16:130-4.

8. Udhayasankar MR, Danya U, Punitha D, Arumugasamy K. Antioxidant activity of Cardiospermum canescens wall. (Sapindaceae)- a wild edible plant from western Ghats. Int J Pharm Pharm Sci 2013;5:322-4.

9. Savitha G, Vishnupriya V, Krishnamohan S, Cardiospermum halicacabum Linn.-A review. Asian J Pharm Chem Res 2017;10:23-6.

10. Vinoth B, Manivasagaperumal R. Phytochemical analysis and antibacterial activity of Cardiospermum halicacabum Linn. Int J Curr Sci Technol 2013;2:9-12.

11. Hari R. Antioxidant activity of combined ethanolic extract of Pisonia grandis and Cardiospermum halicacabum. Int J Pharm Sci Rev Res 2016;39:95-100.

12. Raza SA, Hussain S, Riaz H, Mahmood S. Review of beneficial and remedial aspects of Cardiospermum halicacabum L. Afr J Pharmacol
2013;7:3026-33

13. Annadurai A, Elangovan V, Velmurugan S, Ravikumar R. Preliminary phytochemical screening and antibacterial activity of Medicinal plant Cardiospermum halicacabum L. Adv Appl Sci Res 2013;4:302-8.

14. Aishwarya V, Abdulla SS, Dheeba S, Renuka R. In vitro antioxidant and anticancer activity of Cardiospermum halicacabum L. Against EAC Cell line. Int J Pharm Pharm Sci 2014;6:263-8.

15. Kiresee Saghana PR, Hemalatha S. Free radical scavenging activity of 4-hydroxypropiophenone by in vitro assays. World J Pharm Pharm Sci 2015;4:935-50.

16. Jeyanthi G, Sathishkumar T, Senthilkumar T, Jegadeesan M. In vitro antioxidant studies of Cardiospermum halicacabum L. Var. Luridum (Blume) Adelb seeds. Int J Appl Biol Pharm Technol 2012;3:418-24.

17. Molina GG. DPPH radical scavenging activity and reducing power of balloon vine (Cardiospermum halicacabum Linn.) Leaf. extract. Int J Trend Res Dev 2016;3:531-3.

18. Boligon AA, Machado MM, Athayde ML. Technical evaluation of antioxidant activity. Med Chem 2014;4:517-22

19. Gulcin I, Topal F, Sarikaya SB, Bursal E, Bilsel G, Goren AC. Polyphenol contents and antioxidant properties of medlar (Mespilus germanica L.). Rec Nat Prod 2011;5:158-75.

20. Pham-Huy LA, He H, Pham-Huy C. Free radicals, antioxidants in disease and health. Int J Biomed Sci 2008;4:89-96.

21. Boora F, Chirisa E, Mukanganyama S. Evaluation of nitrite radical scavenging properties of selected zimbanwean plant extracts and their phytoconstituents. J Food Processing 2014;2014: Article ID: 918018, 7.

22. Shareef MI, Mohan Reddy SJ, Gopinath SM, Dayananda KS, Somashekhar R, Mandal A, et al. Superoxide anion scavenging activity of Carthamus tinctorius flower. Int J Innov Res Sci Eng Technol 2014;3:10101-4.

23. Phaniendra A, Jestadi DB, Periyasamy L. Free radicals: Properties, sources, targets and their implication in various diseases. Ind $\mathrm{J}$ Clin Biochem 2015;30:11-26.

24. Bhattacharjee S. Membrane lipid peroxidation and its conflict of interest: The two faces of oxidative stress. Curr Sci 2014;107:1811-23. 